\title{
Penyelidikan Prospek Pasir Besi di Dusun Sungai Topo, Desa Sungai Teluk, Kecamatan Sangkapura, Kabupaten Gresik menggunakan Metode Magnetik
}

\author{
Karimah $^{*}$ and Irjan
}

\begin{abstract}
Ringkasan
Penelitian yang telah dilakukan di Kawasan Pantai Dusun Sungai Topo, Desa Sungai Teluk, Kecamatan Sangkapura, Kabupaten Gresik bertujuan untuk mengetahui pola sebaran pasir besi dan mengetahui struktur bawah permukaan di daerah penelitian. Daerah penelitian memiliki Formasi Quarter Aluvial yang merupakan endapan sungai dan pantai yang tersusun dari kerakal, kerikil, lempung, lumpur, dan pasir. Akuisisi data interpretasi magnetik dalam penelitian ini telah dilakukan pada bulan Juli 2018, diperoleh 103 titik pengamatan dengan jarak $80-100 \mathrm{~m}$ antar titik pengamatan. Pengambilan data dengan menggunakan Proton Precession Magnetometer (PPM) diperoleh medan magnet total di titik pengamatan pada daerah penelitian. Hasil interpretasi kualitatif dengan koreksi variasi harian, koreksi IGRF, kontinuasi ke atas dengan ketinggian $200 \mathrm{~m}$ dan reduksi ke kutub. Hasil analisis menunjukkan rentang nilai anomali medan magnet dari $-70 n T$ sampai $70 n T$. Hasil interprtasi kuantitatif dari pemodelan 2D menggunakan oasis montaj, diperoleh beberapa model benda anomali bawah permukaan.model benda anomali dengan nilai suseptibilitas $15 \times 10^{-6}$ satuan SI diinterpretasi sebagai pasir besi yang berselingan dengan lanau, lempung, pasir dan kerikil dari formasi Alluvium. Formasi ini terletak pada kedalaman $0 m$ sampai $38 m$ di bawah permukaan. Pasir besi yang terdapat pada formasi ini diperkirakan tidak prospek untuk dieksplorasi karena relatif kecil.
\end{abstract}

Kata Kunci : pasir besi, data anomali medan magnet, suseptibilitas batuan.

\begin{abstract}
The research had been conducted in the beach of Sungai Topo Village, Sangkapura, Gresik, to find out the distribution of iron sand and know the structure of the subsurface in the area of research. Areas of research have the Quarter Alluvial Formation which is deposition of the river and the beach is consisted of gravel, clay, sand, and mud. Magnetic data interpretation acquisition in this research has been conducted in July 2018, obtained 103 points of observation with the distance $80-100 \mathrm{~m}$ between the point of observation. Data acquisition by using a Proton Precession Magnetometer (PPM) and obtained the total magnetic field observations on areas of research emphasis. A qualitative interpretation of the results with a daily variation, IGRF correction, upward continuation over $200 \mathrm{~m}$ altitude and the reduction to the pole. The results of the analysis show the range value of magnetic field anomalies from $-70 n T$ to $70 n T$. Quantitative interpretations results from 2D modelling using oasis montaj, obtained some anomalous objects beneath the surface models. Models of objects with a value of susceptibility anomalies 0.0098 cgs unit are interpreted as a special sand iron with silt, clay, sand and gravel Formation of Alluvium. This formation is located at a depth of $0 \mathrm{~m}$ to $38 \mathrm{~m}$ beneath the surface. Iron sand in this formation is estimated to not be a prospect because it is relatively small.
\end{abstract}

Keywords: iron sand; magnetic field anomaly data; rock susceptibility.

\footnotetext{
${ }^{*}$ Correspondence: karimahimei@gmail.com
} 


\section{PENDAHULUAN}

Indonesia merupakan negara yang luas dan mempunyai sumber daya alam yang melimpah pula. Secara geologis kondisi indonesia berada pada pertemuan tiga lempeng yaitu lempeng Indo-Australia, Indo-Eurasia, Eurasia dan lempeng Pasifik. Hal ini mengakibatkan Indonesia mempunyai sebuah tatanan tektonik yang komplek yang secara otomatis akan mendukung potensi sumber daya alam dari kaya akan tambang mineral galian yang cukup besar [1].

Salah satu tambang mineral yang ada di indonesia yaitu pasir besi. Pasir besi adalah sejenis pasir dengan konsentrasi besi yang sangat signifikan, biasanya berwarna abu-abu gelap atau berwarna kehitaman dengan ukuran halus $(<1 \mathrm{~mm})$ dan ukuran kasar $(5-3 \mathrm{~mm})$. Perbedaan karateristik kandungan mineral pasir besi terjadi karena adanya perbedaan lokasi endapan [2]. Pembentukan endapan pasir besi ditentukan oleh beberapa faktor antara lain batuan asal, proses perombakan, media transportasi, proses serta tempat pengendapannya. Sumber mineral endapan pasir besi pantai sebagian besar berasal dari batuan gunung api, terjadinya proses perombakan diakibat pelapukan batuan karena proses alam yang membuat butiran mineral terlepas dari batuan. Proses transportasi membawa material lapukan dari batuan asal, menyebabkan mineral terangkut hingga ke muara, kemudian gelombang dan arus laut mencuci dan memisahkan mineral tersebut berdasarkan berat jenisnya [3].

Bawean, sebuah pulau dilaut jawa merupakan pulau vulkanik dengan berbagai potensi. Salah satu potensinya yaitu tambang mineral galian pasir besi yang terdapat di Dusun Sungai Topo, Desa Sungai Teluk, Kecamatan Sangkapura, Kabupaten Gresik. Sebagian besar pulau Bawean terbentuk dari batuan vulkanik (lava andesit, basal dan tuff) sebagai sumber bijih besi dan batuan lainnya seperti batupasir dan batugamping. Lokasi penelitian berada di Dusun Sungai Topo, Desa Sungai Teluk, Kecamatan Sangkapura, Kabupaten Gresik. Topografi alamnya berupa daratan rendah dengan ketinggian antara 0-36 mdpl. Formasi batuan di daerah penelitian, yaitu Endapan Quarter Aluvium (Qa), merupakan sendimen yang termuda. Batugamping koral berupa terumbu terdapat di sekitar antara beberapa pulau dan masih tumbuh hingga sekarang (Holosen-Resen). Endapan Quarter Aluvium (Qa) tersusun dari beberapa batuan, yaitu kerakal, kerikil, lempung lumpur dan pasir. Satuan ini merupakan endapan sungai dan pantai, umumnya tidak kompak dan

Full list of author information is available at the end of the article ${ }^{\dagger}$ Equal contributor mudah lepas [4]. Kemungkinan besar potensi bijih besi yang ada di Bawean sangat besar. Hal tersebut diindikasi dengan keberadaan singkapan pasir besi di atas permukaan daerah penelitian. Kondisi alam di daerah penelitian sebelumnya belum pernah dilakukan penelitian guna memetakan persebaran dan struktur bawah permukaan pasir besi di daerah tersebut. Oleh karena itu, diperlukan penelitian untuk mengetahui persebaran pasir besi di daerah tersebut dengan menggunakan metode geomagnetik.

Metode magnetik merupakan salah satu metode survei geofisika pasif yang memanfaatkan sifat kemagnetan bumi. Pasir besi mempunyai sifat magnet kuat dan mudah terinduksi oleh medan magnet, sehingga dengan menggunakan metode magnetik diharapkan sebaran pasir besi di area penelitian dapat terpetakan dengan baik. Menurut Ruslita [5] bahwa dengan memanfaatkan sifat kemagnetan bumi pada metode magnetik akan meberikan gambaran persebaran pasir besi di bawah permukaan dengan baik, dan akan menghasilkan kontur yang mendistribusi suseptibilitas batuan di bawah permukaan. Pada nilai suseptibilitas batuan dapat memisahkan batuan satu dengan lainnya sesuai sifat kemagnetan batuan tersebut, sehingga di dapatkan informasi dari arah sebaran dan kedalaman pasir besi. Prinsip kerja metode magnetik di dalam survei geofisika adalah memetakan sumber - sumber anomali bawah permukaan. Anomali magnetik didefinisikan sebagai medan magnetik yang berasal dari distribusi benda bawah permukaan yang termagnetisasi. Suatu volume benda yang terdiri atas mineral-mineral magnetik dapat diasumsikan sebagai dipol magnetik. Besar magnetisasi yang terjadi pada batuan tersebut sesuai dengan rekam jejaknya selama berada di dalam medan magnetik bumi, sehingga magnetisasinya dapat diasumsikan hanya berasal dari induksi magnetik yang diterima dari medan magnetik bumi. Induksi magnetik total seluruh batuan tersebut dapat dirumuskan sebagai berikut [6].

$$
\vec{B}\left(\vec{r}_{0}\right)=C_{m} \nabla \int_{v} \vec{M}(\vec{r}) \cdot \nabla\left[\frac{1}{\left|\vec{r}_{0}-\vec{r}\right|}\right] d v
$$

Induksi magnetik di dalam persamaan (1) disebut anomali magnetik. Anomali magnetik bersama-sama dengan medan magnetik utama bumi $B_{0}$ selalu berada di setiap titik di permukaan bumi. Oleh karena itu, medan magnetik total yang terukur pada peralatan di permukaan bumi adalah gabungan nilai medan magnetik utama bumi $\left(\vec{B}_{0}\right)$ dan anomali magnetik $\left(\vec{B}_{r 0}\right)$ dengan asumsi bahwa medan magnetik luar dapat diabaikan. Berdasarkan hal ini nilai medan 
magnetik total $\left(\vec{B}_{T}\right)$ yang terukur dapat dinyatakan dengan persamaan

$$
\vec{B}_{T}=\vec{B}_{0}+\vec{B}_{r 0}
$$

\section{METODE PENELITIAN}

Metode pengukuran data medan magnetik total telah dilaksanakan di Dusun Sungai Topo, Kecamatan Sangkapura, Kabupaten Gresik pada tanggal 4-6 Juli 2018 dengan peta lokasi seperti Gambar 1. Peralatan yang digunakan pada penelitian antara lain Proton Precession Magnetometers (PPM), Global Positioning System (GPS), kompas geologi, peta geologi, laptop, serta beberapa program aplikasi dan perangkat lunak seperti Microsoft Excel 2007, Surfer 13, Oasis Montaj, dan Sketchup.

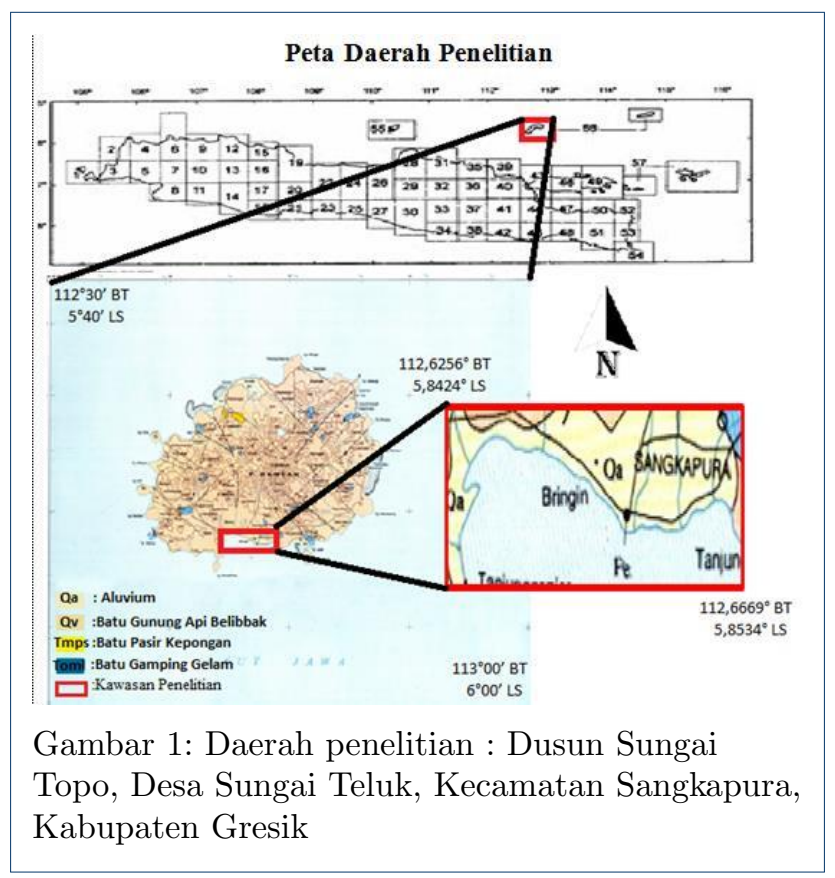

Tahapan kegiatan penelitian yang dilakukan meliputi pengukuran data medan magnet total, pengolahan, pemodelan, dan interpretasi data, Gambar 2. Data yang terukur di lapangan adalah induksi magnetik total, posisi geografis (lintang, bujur, ketinggian), waktu (jam dan menit), dan kondisi lingkungan. Selanjutnya dilakukan koreksi terhadap data medan magnet total yang meliputi koreksi harian dan koreksi IGRF, sehingga diperoleh data anomali magnetik total. Data anomali magnetik total yang masih terdistribusi di permukaan topografi tersebut selanjutnya ditransformasi ke bidang datar dan dikoreksi dari efek magnetik regional, sehingga diperoleh data anomali magnetik lokal. Selanjutnya data anomali magnetik lokal ini dimodelkan menggunakan perangkat lunak Oasis Montaj untuk menginterpretasi jenis.

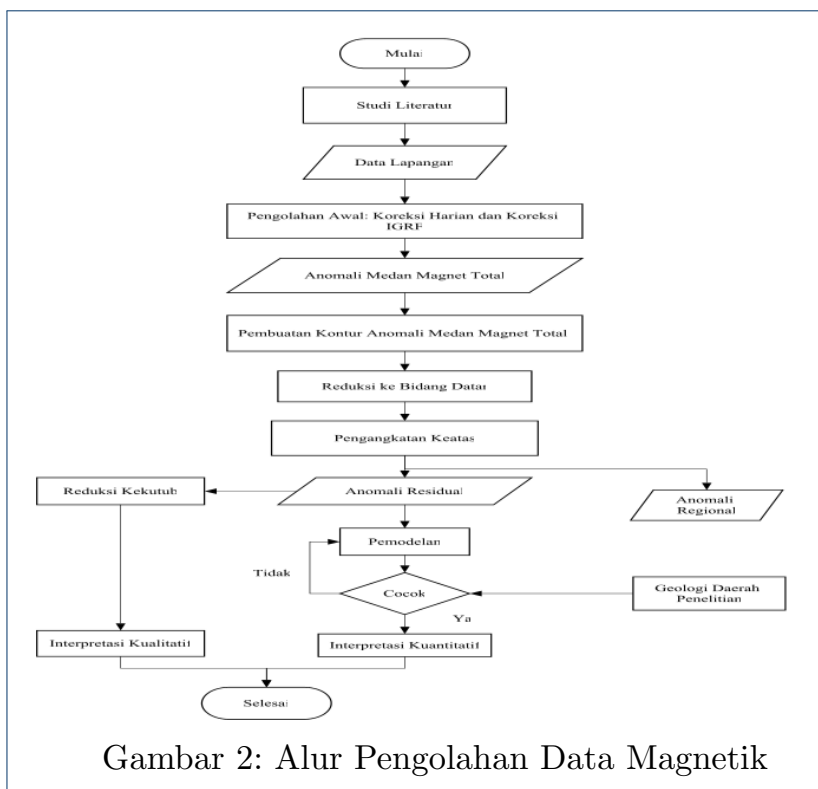

\section{HASIL DAN PEMBAHASAN}

Data magnet total yang diperoleh dari pengukuran masih bercampur dengan data medan magnet utama bumi dan medan magnet luar. Untuk memperoleh data anomali magnetik total yang menjadi target penelitian, maka dilakukan koreksi yang terdiri atas koreksi harian (koreksi medan magnet luar) dan koreksi IGRF (koreksi medan magnet bumi). Data anomali magnetik yang diperoleh setelah dilakukan koreksi tersebut, selanjutnya dikonturkan menggunakan Surfer 13, sehingga diperoleh peta kontur seperti ditunjukkan pada Gambar 3(a).

Data anomali magnetik total masih terdistribusi di atas permukaan topografi, sehingga perlu ditransformasi ke bidang datar. Metode yang dapat digunakan untuk mentransformasi data anomali ke bidang datar adalah pendekatan deret Taylor [6].

Reduksi Bidang datar dilakukan untuk mereduksi pengaruh variasi jarak vertikal antara sumber anomali terhadap titik pengukuran di topografi. Sistem coba-coba dilakukan dengan ketinggian bidang pengamatan yang sama yaitu 20m, dan variasi kedalaman bidang ekuivalen $350 \mathrm{~m}, 300 \mathrm{~m}$, $250 m, 200 m, 150 m$, dan $148 m$. Dari beberapa percobaan yang telah dilakukan proses transformasi ke bidang datar cukup stabil pada ketinggian bidang pengamatan $20 \mathrm{~m}$ dan kedalaman $148 \mathrm{~m}$. Secara teknis transformasi ini dilakukan menggunakan program Matlab. Data anomali yang dihasilkan dari proses ini telah terdistribusi pada bidang datar, dan di kontur di 
Surfer 13, sehingga diperoleh kontur anomali medan magnet total yang telah direduksi ke bidang datar, seperti Gambar 3(b).

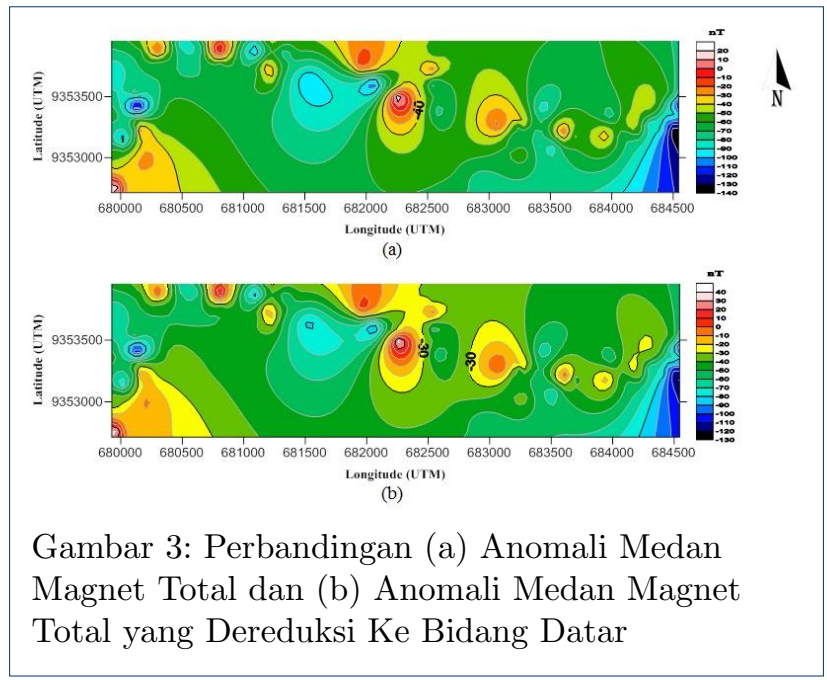

Data anomali magnetik total yang telah berada pada bidang datar, selanjutnya dikoreksi dari efek magnetik regional, karena target penelitian adalah batuan bawah permukaan yang bersifat lokal. Data anomali magnetik regional dapat diperoleh melalui pengangkatan ke atas (upward continuation) data anomali magnetik total yang telah berada pada bidang datar hingga ketinggian tertentu, sedemikian hingga pola kontur anomalinya cenderung tetap. Pada penelitian ini anomali magnetik regional diperoleh pada ketinggian 2000mdpl dengan menggunakan software MagPick [6].

Setelah dilakukan pemisahan antara anomali regional dengan anomali lokal, diperoleh anomali lokal, Interpretasi sumber anomali bawah permukaan dilakukan melalui pemodelan menggunakan perangkat lunak Oasis Montaj. Untuk melakukan pemodelan, dibuat beberapa sayatan (line section) di atas zona dipol magnetik pada peta kontur anomali magnetik lokal yang diperkirakan sebagai sumber anomali magnetik bawah permukaan seperti terlihat pada Gambar 5.

Data anomali magnetik diekstrak dari sayatan-sayatan tersebut menggunakan perangkat lunak Surfer13 dan selanjutnya disebut sebagai data anomali observasi. Gambar 4. Pada gambar 5 diperoleh tiga sayatan, yaitu lintasan A-A', lintasan B-B' dan lintasan C-C' pada peta kontur anomali magnetik lokal. Pemodelan 2D ini dilakukan menggunakan Software Oasis Montaj dengan menggunakan inputan berupa data topografi dan data anomali lokal. Prinsip kerja dari Software Oasis Montaj adalah menggunakan konsep forward
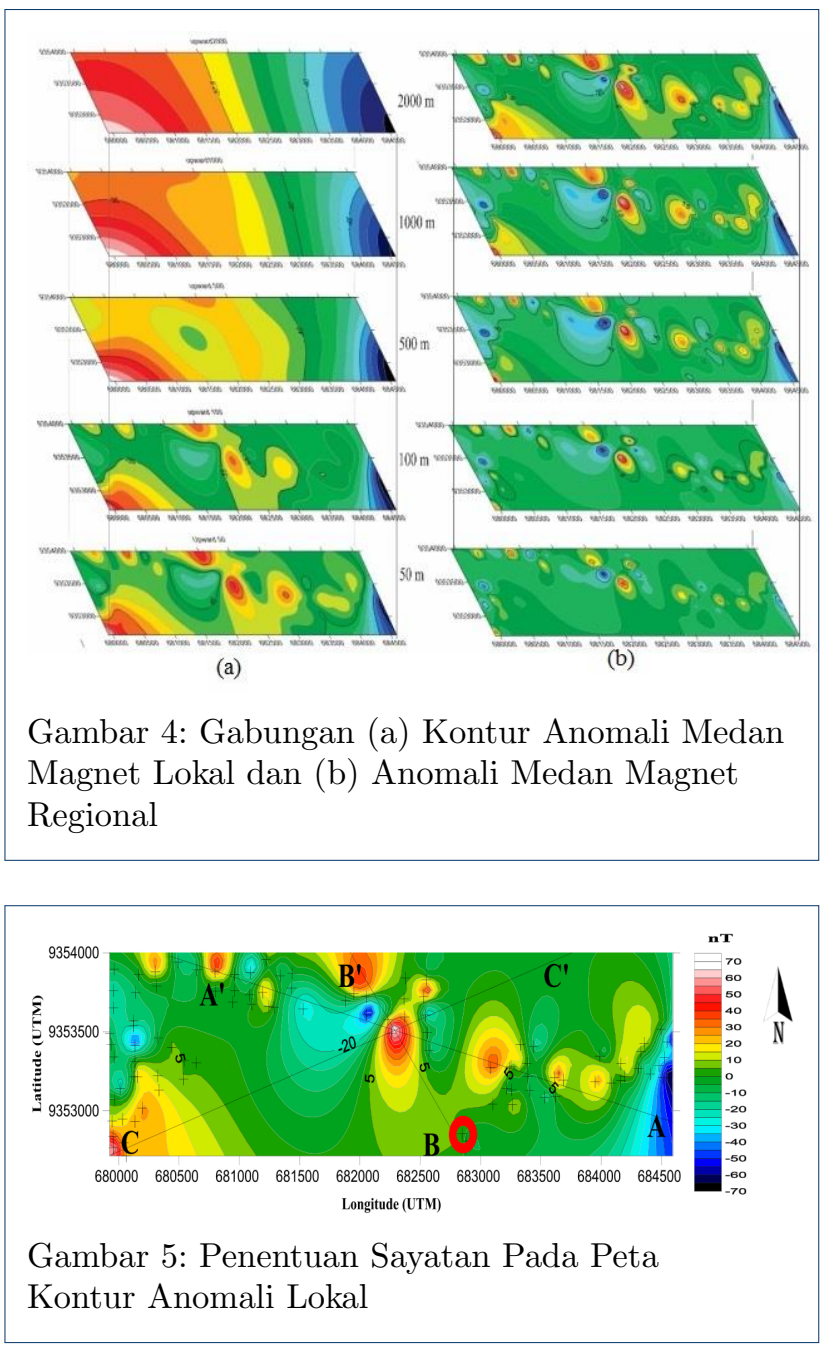

Modeling (pemodelan tidak langsung) dengan menyamakan bentuk dari anomali pengamatan (observed) yang berupa garis putus-putus dengan anomali perhitungan (calculated) yang berupa garis tegas, secara tidak langsung penyamaan tersebut bersimulasi menggambarkan model dan kedalaman benda anomali atau struktur geologinya. Penyamaan dari anomali pengamatan dengan perhitungan dilakukan dengan trial dan error, karena semakin kecil error perhitungan terhadap error referensi akan menunjukkan ke validan pada pemodelan yang dilakukan. Dalam interpretasi kuantitatif masih terdapat ambiguitas karena bisa saja beragam model, geometri, dan kedalaman yang tidak pasti dapat dihasilkan. Untuk menghindari hal demikian maka perlu adanya data pedukung yang berupa data geologi daerah penelitian, data singkapan dan data geofisikanya.

Berdasarkan interpretasi pada model penampang lintasan A-A', B-B', C-C' didapat empat model 


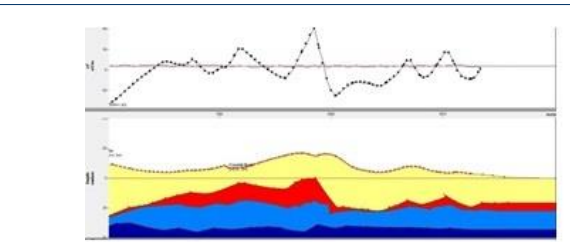

(a)

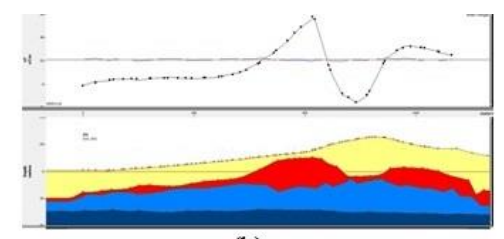

(b)

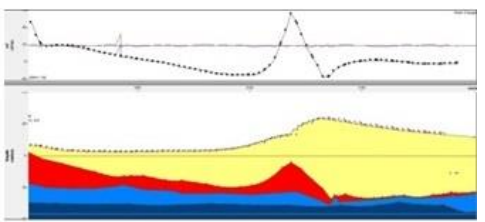

(c)

Gambar 6: (a) lintasan A-A', (b) lintasan B-B', (c) lintasan C-C'

lapisan, yaitu model pertama (warna kuning), model kedua (warna merah), model ketiga (warna biru), model keempat (warna biru dongker). Pada model pertama ditandai dengan warna kuning mempunyai suseptibilitas 0.00016 dalan satuan cgs dengan kedalaman antara $0 \mathrm{~m}$ sampai $33.57 \mathrm{~m}$ memiliki batuan dominan pasir. Pada model kedua ditandai dengan warna merah mempunyai suseptibilitas 0.0098 dalam satuan cgs dengan kedalaman antara $0 m$ sampai $38.39 m$ memiliki batuan dominan batuan dominan batupasir (batupasir yang bercampur dengan pasir, dan pasir besi). Pada body yang berwarna merah merupakan dugaan adanya campuran pasir besi yang ada di bawah permukaan pada daerah penelitian, dengan menunjukkan pengaruh nilai anomali model terhadap anomali referensi yang lebih besar dari model yang lainnya. Formasi ini diduga sebagai sandstone dengan parameter peta geologi, stratigrafi dan data singkapan.

Pada Pemodelan 3 Dimensi (3D) merupakan hasil gabungan dari pemodelan 2 Dimensi (2D) pada model A-A', B-B', dan C-C' menggunakan bantuan software Sketchup. Hasil lapisan pemodelan 3D menggambarkan sebaran dan struktur bawah permukaannya secara jelas dan nyata.pada daerah penelitian, sehingga akan memudahkan proses interpretasi secara vertikal.

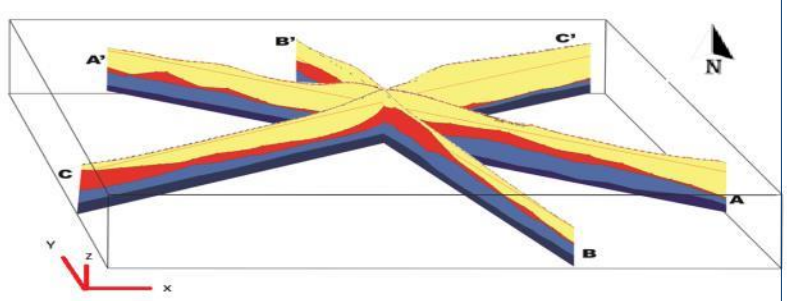

Gambar 7: Model 3D Penampang Lintasan A-A', B-B', C-C'

Interpretasi terhadap hasil pemodelan anomali magnetik pada sayatan AA', BB', dan CC' didasarkan pada Peta Geologi Lembar Bawean-Masalembu.
Berdasarkan peta ini, formasi batuan bawah permukaan di daerah penelitian tersusun atas Formasi Qa (Quarter aluvium) [1]. Litologi daerah penelitian didominasi perselingan batupasir dan pasir besi yang termasuk Formasi Qa dengan estimasi suseptibilitas magnetik rata-rata sebesar 0, 0098cgs. Pada body yang berwarna merah merupakan dugaan adanya campuran pasir besi yang ada dibawah permukaan pada daerah penelitian, dengan menunjukkan pengaruh nilai anomali model terhadap anomali referensi yang lebih besar dari model yang lainnya. Formasi ini diduga sebagai sandstone dengan parameter peta geologi, stratigrafi dan data singkapan. Batupasir adalah jenis batuan dengan porositas tinggi. Mineralisasi besi diperkirakan banyak terjadi di dalam formasi ini, khususnya perselingan pasir halus dan batupasir.

\section{KESIMPULAN}

Berdasarkan hasil pengolahan data interpretasi dan pembahasan dapat disimpulkan seagai berikut:

1 Berdasarkan anomali magnet lokal pada daerah penelitian terbagi menjadi dua, yaitu anomali tinggi dan anomali rendah dengan bentuk klosur tertutup yang tersebar secara tidak merata di area penelitian.

2 Berdasarkan data singkapan, stratigrafi, geologi dan data geofisika, area penelitian memiliki empat model lapisan struktur bawah permukaan yang tersusun dari pasir halus, pasir yang bercampur dengan pasir besi, gamping bercampur dengan batu basir dan gamping dengan kedalam $50 m$ di bawah permukaan.

\section{PENULIS}

1 Karimah

Dari :

(1) Jurusan Fisika Fakultas Sanis dan Teknologi, Uiversitas Islam Negeri Maulana Malik Ibrahim Malang

2 Irjan

Dari : 
(1) Jurusan Fisika Fakultas Sanis dan Teknologi, Uiversitas Islam Negeri Maulana Malik Ibrahim Malang

Pustaka

1. Fitri I, KEBUMIAN FIDANT. Analisis Kandungan Mineral Logam ingkapan Batuan Dikawasan Pertambangan Mangan Desa Kumbewaha Kecamatan Siotapina Kabupaten Buton dengan Menggunakan Metode X-RF. Kendari: Program Studi Geofisika, Fakultas Bumi dan Teknologi Kebumian, Universitas Haluoleo. 2016;

2. Purwanto S, Dani M. Strukturmikro dan Sifat Magnet Pasir Besi Pasca Ultrasonifikasi. Jurnal Sains Materi Indonesia. 2017;19(1):14-18.

3. Geologi Pasir Besi : Genesa dan Sifat Fisik; 2016. Available from: https://www.geologinesia.com/2016/12/geologi-pasir-besigenesa-dan-sifat-fisik.html.

4. Aziz S, Hardjoprawiro S, Mangga SA. Peta Geologi Lembar Bawean dan Masalembo, Jawa. Pusat Penelitian dan Pengembangan Geologi Bandung. 1993;

5. Rusita S, Siregar SS, Sota I. Identifikasi Sebaran Bijih Besi Dengan Metode Geomagnet di Daerah Pemalongan, Bajuin Tanah Laut. Jurnal Fisika Flux: Jurnal Ilmiah Fisika FMIPA Universitas Lambung Mangkurat. 2016;13(1):49-59.

6. Telford WM, Telford WM, Geldart LP, Sheriff RE, Sheriff RE. Applied geophysics. Cambridge university press; 1990. 